\title{
Overcoming the Hurdles to Accountability in UN Peacekeeping
}

\section{Introduction to the Special Issue}

\author{
Yohei Okada* \\ Graduate School of International Cooperation Studies, Kobe University, 2-1 \\ Rokkodai-cho, Nada-ku, Kobe, Japan \\ okada@port.kobe-u.ac.jp
}

\begin{abstract}
Nigel D. White**
Nottingham International Law and Security Centre, School of Law, University of Nottingham, University Park, Nottingham, United Kingdom nigel.white@nottingham.ac.uk
\end{abstract}

Peacekeeping is a creation of the United Nations (UN) and it plays a pivotal role in UN endeavours to maintain international peace and security. However, peacekeeping has also generated a backlash. Despite the presence of UN peacekeepers, the genocides in Rwanda and Srebrenica in the mid-199os could not be prevented. Not only have peacekeepers failed to protect civilians, UN peacekeeping operations have also occasionally been a source of harm to the local population. Sexual exploitation and abuse by peacekeepers has seriously tainted the UN's reputation and, so far, no initiatives have successfully eradicated it. The cholera outbreak in Haiti is a clear example of the negative consequences that peacekeeping may have for vulnerable communities in a country. Against this background, it has been said that UN peacekeeping operations should be carried out in a more accountable manner by providing redress to victims and taking effective measures to prevent harmful conduct by peacekeepers. ${ }^{1}$ Although no one would object to this general proposition, the ways in

* Associate Professor of International Law, Graduate School of International Cooperation Studies, Kobe University.

** Professor of Public International Law, School of Law, University of Nottingham; Visiting Professor, Graduate School of International Cooperation Studies, Kobe University, November 2019.

1 For instance, the International Organizations Law Review's recent special issue, 'The Accountability of International Organizations', mainly focuses on the practice of UN peacekeeping. 
which it can be achieved are not straightforward: there are multiple impediments to holding the UN and other actors (troop contributing nations (TCNs), individual peacekeepers and contractors) accountable for peacekeeping failures and abuses.

First, as a practical hurdle, the UN is entitled to invoke jurisdictional immunity before domestic courts, notwithstanding the UN's failure to provide adequate internal mechanisms for settling third party claims. Consequently, alleged victims of UN peacekeepers' misconduct are often left without any effective procedures to hold the UN (or its agents) accountable. Second, UN peacekeeping operations rely on outsourcing to member states and the private sector. This complicates accountability and requires resolution on a case-bycase basis. Third, the UN is an inter-governmental organisation with its own international legal personality, but it remains unclear which international obligations are binding upon the UN. In other words, the standards against which UN accountability is assessed have not yet been fully explored. Lastly, as a conceptual hurdle, the term 'accountability' itself has vague contours. While some use it as a synonym for legal responsibility, others attempt to assign broader attributes to the concept.

In November 2019, the Graduate School of International Cooperation Studies (GSICS) at Kobe University hosted a symposium to discuss these issues. The contributions in this special issue are based on the presentations and conversations held there. First, Yohei Okada addresses the issues of immunity and attribution of conduct. The UN's jurisdictional immunity is now under attack because, in cases of third party claims, immunity often leads to a denial of justice. With a view to breaking the deadlock, one may think of depriving the UN of immunity or, at least, restricting it. Another option is to circumvent the immunity by attributing peacekeepers' conduct to TCNs that do not enjoy immunity before their own courts. However, Okada argues that neither approach is an appropriate solution, and suggests instead that the UN strengthen alternative means of settling third party claims fairly.

The second contribution, by Norihito Samata, digs deeper into the concept of accountability and explores its non-judicial aspects. It is true that legal responsibility for internationally wrongful acts and victims' access to judicial

See, e.g., K. E. Boon and F. Mégret, 'New Approaches to the Accountability of International Organizations', International Organizations Law Review, vol. 16, 2019, pp. 1-10. See also C. M. Chinkin, 'United Nations Accountability for Violations of International Human Rights Law', Recueil des cours, vol. 395, 2018, pp. 199-319. 
process constitute integral parts of accountability. However, they do not completely represent the entire breadth of the concept of accountability. Non- or quasi-judicial mechanisms for enhancing the accountability of international organisations have been developed in the context of international financial institutions (IFIs), such as the World Bank. To fill the accountability gap in UN peacekeeping, some lessons can be applied from the IF Is' unique accountability mechanisms.

In the third contribution, Martina Buscemi tackles one of the unexplored issues that is of great significance in recent peacekeeping operations: UN responsibility for and in relation to misconduct committed by private contractors entrusted with non-military missions. She analyses the public procurement process within the UN and illustrates how private contractors can harm the local population. At least a few cases have already been reported. Buscemi's contribution deals with a private contractor's mismanagement of sanitary waste in Haiti and misuse of unarmed drones in the Democratic Republic of the Congo, both of which caused serious damage to a number of inhabitants in the host countries. The contribution clarifies the legal framework for regulating the UN's direct and indirect responsibility for private contractors' misconduct.

In the last contribution to this special issue, Nigel D. White investigates how human rights due diligence obligations are applied, accepted and implemented in UN peacekeeping operations. The UN, unlike states, possesses a limited competence: thus, we cannot take for granted that the organisation has the same due diligence obligations as states. Although there are some indications that the UN regards itself as bound by certain due diligence obligations, those indications are scattered and have not been systematically examined. White's contribution fills this knowledge gap and, further, argues that the UN should not only be bound by norms of due diligence, but also is in fact bound by them either under customary international human rights law, or under the UN's internal law.

This special issue does not aim to cover all the issues relating to accountability in UN peacekeeping, but it does seek to highlight how accountability may be shared by relevant actors by considering methods of overcoming the hurdles of immunity, attribution, access to justice, and uncertainty as to the legal obligations placed upon the key actor in peacekeeping - the UN. The criminal responsibility of individual peacekeepers is not the subject of separate discussion, but the low level of criminal convictions can be seen as a clear indication that neither the UN nor TCNs are taking their obligations to punish and prevent abuse seriously, and that lack of intent is in itself a hurdle 
to accountability. By exploring key areas of peacekeeping law and practice, we hope that this special issue will contribute towards clarifying where we currently stand and where we are going in our quest to overcome the hurdles to accountability in $\mathrm{UN}$ peacekeeping. 